\title{
Selective Feeding by Atlantic Herring (Clupea harengus) Larvae on Zooplankton in Natural Assemblages*
}

\author{
David M. Checkley, Jr. \\ Marine Science Institute, The University of Texas at Austin, Port Aransas, Texas 78373, USA
}

\begin{abstract}
The hypothesis that larval herring Clupea harengus select food by type as well as size was tested in laboratory experiments. Herring larvae were reared at 7 to $9{ }^{\circ} \mathrm{C}$ on wild zooplankton. The percentage of herring larvae with food at day's end increased from $4 \%$ (4 d) to $68 \%(9 \mathrm{~d})$ and averaged $83 \%$ for larvae 25 to $74 \mathrm{~d}$ old. Larval herring selected particles according to type as well as size; this selectivity varied with larval age and hence size. Copepod nauplii and copepodites were preferred by larvae of all sizes. Among copepodites, Pseudocalanus sp. and Oithona sp. were preferred by smaller and larger larvae, respectively, while Acartia sp. was rarely ingested, even when of acceptable size. Mollusc veligers comprised a significant portion of the diet of young ( 4 to $24 \mathrm{~d}$ ) larvae but were actively rejected by older larvae even when perceived and of acceptable size. Particles smaller than the largest acceptable size were consistently preferred, atypical of predation by vertebrates. These results indicate that larval herring select prey according to type as well as size and that this behavior is acquired through experience.
\end{abstract}

\section{INTRODUCTION}

Larvae of the Atlantic herring Clupea harengus are visual predators on the plankton. Feeding behavior consists of particle perception, assumption of an Sshaped strike posture, attack, and capture (Rosenthal and Hempel, 1970). Selective ingestion of a particular food out of an available particle assemblage might result from its high visibility, high capture probability, or preference (cf. Murdoch, 1969) by herring larvae. Hence, particle characteristics of potential significance to selection include size and type which, in turn, includes the specific attributes of shape, inherent contrast, and movement. Particle size has been the primary variable considered in studies of planktonic food selection. Food particles must be narrower than the mouth diameter (Blaxter, 1965; Shirota, 1970). The maximum distance that a particle is perceived by fish larvae is positively related to its size (Ware, 1973; Werner and Hall, 1974). According to optimal foraging theory, when 2 or more particles are perceived simultaneously, a predator should chose the largest accept-

\footnotetext{
- The University of Texas Marine Science Institute Contribu-
} tion No. 543 able particle (Confer and Blades, 1975; Pyke et al. 1977). Hence, on the basis of particle size alone, the largest acceptable particles are expected to comprise a larger fraction of the diet than of the assemblage available to herring larvae, typical of predation by vertebrates (Brooks and Dodson, 1965).

The types of food observed in the guts of herring larvae collected at sea are phytoplankton and zooplankton, especially copepod nauplii, copepodites, and larval invertebrates (Hardy, 1924; Lebour, 1924, 1933; Marshall et al., 1937; Bhattacharyya, 1957; Sherman and Honey, 1971; Schnack, 1972; Last, 1980; Cohen and Lough, 1981). Reared herring larvae offered wild plankton also ingest these prey types (Blaxter, 1965; Rosenthal and Hempel, 1970). In these cases, however, the available particle assemblages were not known precisely and, hence, information on food selection is unavailable.

In the present study, I test the hypothesis that herring larvae select food on the basis of prey type as well as size. Herring larvae were reared with wild plankton as food. Selection experiments were conducted periodically and the types and sizes of available and ingested particles were compared and related to the length of larval herring. Complementary observations of 
rejected particles were made on one occasion. The results show that herring larvae select food on the basis of type as well as size and suggest that this behavior is acquired through experience.

\section{MATERLALS AND METHODS}

Gametes from autumn-spawning herring collected near the Isle of Man were fertilized in the laboratory and incubated at 7 to $9^{\circ} \mathrm{C}$ (cf. Blaxter, 1968). The resultant larvae were reared at $9^{\circ} \mathrm{C}$ in 98 -l black tubs with overhead fluorescent illumination on a $14 \mathrm{~L}: 10 \mathrm{D}$ cycle. Seawater circulated between a reservoir and the rearing tubs. Approximately one fourth of the system's water was replaced every $2 \mathrm{~d}$ with filtered $(30 \mu \mathrm{m})$ seawater from Loch Ewe on the west coast of Scotland. Plankton was collected every 2 to $3 \mathrm{~d}$ from the upper $3 \mathrm{~m}$ of Aberdeen Bay with a $60-\mu \mathrm{m}$ mesh net, filtered (500 to $1000 \mu \mathrm{m}$ ) to remove predators such as Lernaeocera sp. (Rosenthal, 1967), and let stand at 7 to $9{ }^{\circ} \mathrm{C}$. Sediment was removed each morning by siphoning and the remaining plankton was added to the rearing tubs. Sediment in the tubs, including feces and dead plankton and larvae, was removed daily by siphoning. Live herring larvae were removed by pipette or beaker for inspection or experimentation.

Selection experiments were conducted under similar conditions of light and temperature in black plastic tubs containing 27 or $98 \mathrm{l}$ of filtered $(30 \mu \mathrm{m})$ Loch Ewe seawater to which plankton was added. Plankton was collected with either a 60 - or $250-\mu \mathrm{m}$ mesh net from the surface waters of Aberdeen Bay or Loch Ewe, filtered (132 to $1000 \mu \mathrm{m}$ ) to remove large particles, sampled for dry weight measurement $\left(60^{\circ} \mathrm{C}, 24 \mathrm{~h}\right)$, and let stand overnight at 7 to $9^{\circ} \mathrm{C}$. Sediment was siphoned away the following morning and the remaining plankton mixed, subsampled for dry weight measurement, and aliquots were added to the experimental tubs to make an approximate final concentration of $0.20 \mathrm{mg}$ dry wt $\mathrm{l}^{-1}$ (10-250 particles $\mathrm{l}^{-1}$ ). Aliquots (>500 particles) of plankton were also preserved in dilute Formalin for microscopic analysis. Herring larvae were transferred from rearing to experimental containers before dawn. In late afternoon and evening, individual larvae were removed, anaesthetized with MS-222, and observed under a dissecting microscope. Anaesthetized herring larvae are transparent, except for melanophoes (Fig. 1); hence, each food item was identified and its width and length measured using an ocular micrometer. Fish larvae were then measured, rinsed with distilled water, dried $\left(24 \mathrm{~h}, 60^{\circ} \mathrm{C}\right)$, and weighed. An aliquot (>500 particles) of the final available particle assemblage was retained on a $30-\mu m$ mesh filter and preserved in dilute Formalin for later analysis. Particles in the preserved samples were identified, enumerated, and their length and width measured under a dissecting microscope.

On one occasion, particles rejected by herring larvae were sampled in addition to those available and ingested. Rejected particles were investigated by herring larvae in the S-shaped strike posture but not attacked. Particles rejected in the upper $8 \mathrm{~cm}$ of water were removed with a micropipette and identified and measured under a dissecting microscope.

Alpha (Chesson, 1978) was used as a measure of food preference:

$$
\alpha_{i}=\frac{r_{i}}{n_{1}}\left(\sum_{i=1}^{\mathrm{m}} \frac{r_{i}}{n_{1}}\right)^{-1}
$$

where the portion, in terms of numbers, of particle type $i$ in the ingested food $=I_{i}$; in the available particulate matter $=n_{i} ; \mathrm{m}=$ number of particulate types considered. Alpha ranges from 1 (exclusive ingestion) to 0 (no ingestion) for a particle type and measures the preference for prey type $i$ relative to other prey types considered. Beta, an index of particle rejection, was computed similarly:

$$
\beta_{i}=\frac{q_{i}}{n_{i}}\left(\sum_{i=1}^{\mathrm{m}} \frac{q_{i}}{n_{l}}\right)^{-1}
$$

where $q_{1}=$ portion of particle type $i$ in the assemblage of rejected particles. Beta ranges from 0 (no rejection) to 1 (exclusive rejection). Chi-square was computed using the frequencies of available and ingested or rejected particles in most cases where alpha and beta were computed.

\section{RESULTS}

The length of herring larvae at age $4 \mathrm{~d}$, when feeding was first observed, was $10.4 \pm 0.1 \mathrm{~mm}$ $(\overline{\mathrm{x}} \pm 95 \% \mathrm{CL}[\overline{\mathrm{x}}])$. Most fish absorbed all their yolk by age $6 \mathrm{~d}$. The portion of herring larvae with food at day's end was asymptotically related to the age of larvae, rising from $4 \%$ (age 4 d) to $68 \%$ (age $9 \mathrm{~d}$ ) and

Table 1. Clupea harengus. Composition of diets of young (4-24 d) and old (25-74 d) larvae. Young herring had fed most recently in rearing containers and old herring had fed most recently in selection experiments. The null hypothesis that larval age and prey type are unrelated is discredited $\left(\chi_{7}^{2}=471.7, \mathrm{p}<0.001\right)$

\begin{tabular}{|lrrrr|}
\hline & \multicolumn{4}{c}{ Age range (d) } \\
Prey type & No. $\begin{array}{c}\text { 24 } \\
\text { Decimal } \\
\text { fraction }\end{array}$ & No. & $\begin{array}{l}\text { Decimal } \\
\text { fraction }\end{array}$ \\
\hline Copepod nauplii & 255 & .54 & 807 & .44 \\
Copepodites & 107 & .22 & 994 & .55 \\
Mollusc veligers & 57 & 12 & 6 & 0 \\
Miscellaneous & 55 & 12 & 2 & .01 \\
\hline
\end{tabular}



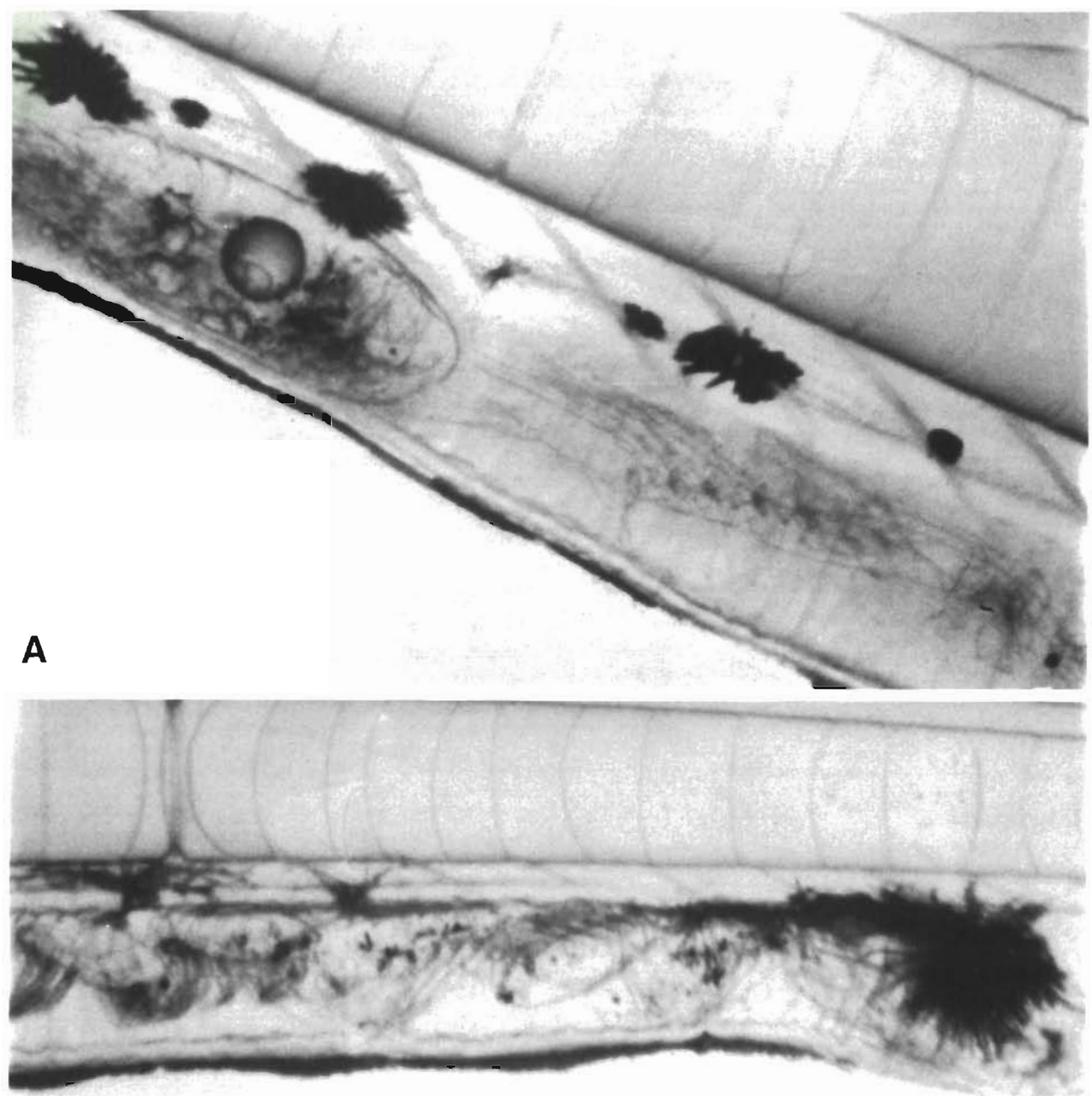

B

Fig. 1. Clupea harengus. Photomicrographs of guts of anaesthetized larvae containing copepodites of (A) Pseudocalanus sp. (left) and Acartia sp. (right), and (B) Oithona sp. Note undigested oil in Pseudocalanus sp. cephalothorax

averaging $83 \pm 12 \%$ for larvae 25-74 days old (11-22 mm standard length, respectively). Fish inspected prior to dawn contained little or no food in their guts.

\section{Larval Diets}

The composition of the diets of fish from first feeding until age $24 \mathrm{~d}$ and from ages 25 to $74 \mathrm{~d}$ is shown in
Table 1. Copepod nauplii were the numerically dominant food of young herring larvae, although significant numbers of mollusc veligers and other types of food were also ingested. By contrast, copepodites were the numerically dominant food of older herring larvae; food types other than copepods, including mollusc veligers, comprised less than $1 \%$ of their diets. The null hypothesis that the age of herring larvae and prey type are not associated was rejected $\left(\chi_{7}^{2}=471.7\right.$, 


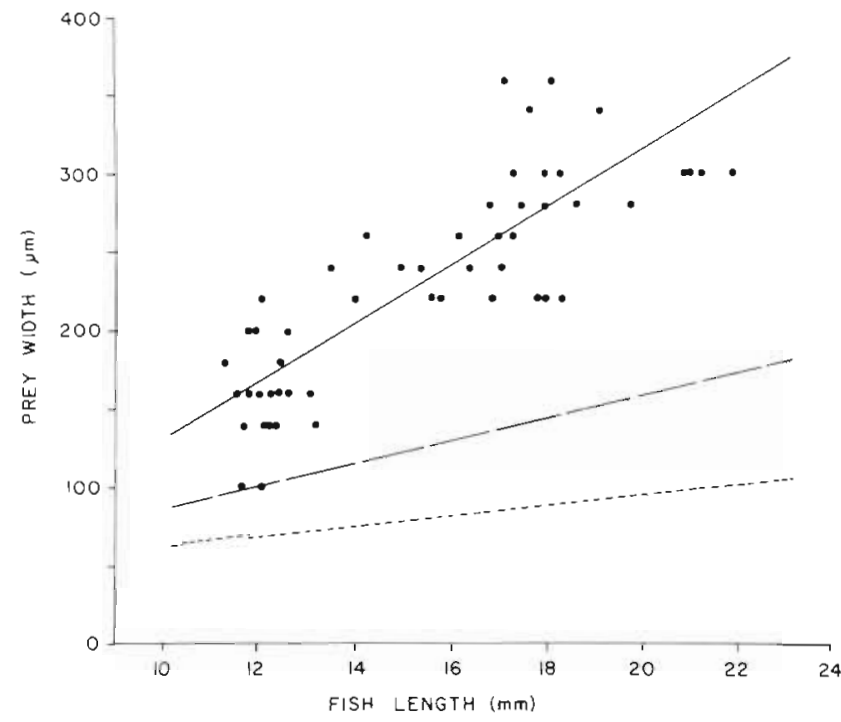

Fig. 2. Clupea harengus. Prey width in relation to fish length. Dots represent width of widest prey for individual fish in selection experiments with a large (>500 $\mu \mathrm{m}$-mesh) prefilter. Dependent variables in linear regressions: solid line, width of widest prey in fish selection experiments with large (>500 $\mathrm{mm}$-mesh) prefilter $\left(r^{2}=0.68, N=52\right)$; dashed line, average width of prey in fish in all selection experiments (values not shown, $r^{2}=0.32, N=103$ ); dotted line, width of narrowest prey in fish in all selection experiments (values not shown, $\left.r^{2}=0.09, N=103\right)$. Each regression is significant $(p<0.005)$

$p<.001)_{\text {; }}$ the deviation of observed from expected frequencies was greatest for mollusc veligers and miscellaneous other types of prey $\left(81 \%\right.$ of $\left.\chi^{2}\right)$.

Larger herring larvae ingested wider prey than did smaller larvae. The width of the widest prey in individual fish increased significantly with fish length. The width of widest prey in individual fish is shown regressed on fish length in Fig. 2, together with regressions of average and minimum prey width on length for all experimental fish. All herring larvae were capable of ingesting significantly wider prey than normally ingested.

\section{Food Selection}

Small herring larvae selected copepod nauplii and large herring larvae selected several types of copepodites (Table 2). The frequencies of particle types available and ingested were significantly different (Table 3). Mollusc veligers, though available, were rarely ingested. If only prey narrower than the widest prey normally ingested by fish of a particular size (i.e. less than the upper regression in Fig. 2) are used to calculate alpha, the same results obtain as in Tables 2 and 3. Hence, the larger size of copepodites did not physically preclude their ingestion by small fish. Alpha for copepod nauplii, copepodites, and mollusc veligers is shown in relation to fish length in Table $4 \mathrm{a}$. Only experiments in which all 3 particle types were available were considered. Herring larvae switched their preference from nauplii to copepodites at approximately $17 \mathrm{~mm}$. Mollusc veligers were consistently absent from the diets of fish in all selection experiments. The relative preference for copepodites was calculated for each experiment in which significant numbers of Pseudocalanus sp., Acartia sp., Oithona sp. were present (Table $4 \mathrm{~b}$ ). The data indicate an increase in preference for Oithona sp. and a decrease in preference for Pseudocalanus sp. as herring larvae grow and an absence of Acartia sp. in the diet of all larvae.

Herring larvae selected particles narrower than the widest they were capable of ingesting. For each experiment, alpha was calculated for categories of particle width that contained significant numbers of available particles. In the first case, all particle types were considered (Fig. 3, filled circles). Only in Experiment 4 were

Table 2. Clupea harengus. Alpha for particle types in each experiment. Blanks are shown where too few particles of a particular type were available in an experiment

\begin{tabular}{|c|c|c|c|c|c|c|c|c|c|c|c|c|c|}
\hline \multirow[b]{2}{*}{ Particle type } & \multicolumn{13}{|c|}{ Experiment } \\
\hline & $1 \mathrm{~A}$ & $1 \mathrm{~B}$ & $2 \mathrm{~A}$ & $2 \mathrm{~B}$ & $2 \mathrm{C}$ & $3 \mathrm{~A}$ & $3 \mathrm{~B}$ & 4 & $5 \mathrm{~A}$ & $5 \mathrm{~B}$ & $6 \mathrm{~A}$ & $6 \mathrm{~B}$ & 7 \\
\hline Copepod nauplii & .53 & .66 & 1.0 & .91 & 1.0 & .54 & & .94 & .44 & .31 & 0 & & .01 \\
\hline Pseudocalanus sp., copepodites & .30 & .27 & & .09 & 0 & .27 & 35 & & 17 & & 30 & .03 & .57 \\
\hline Acartia sp., copepodites & 0 & .02 & & & & .02 & .05 & & & .33 & & .01 & .04 \\
\hline Oithona sp., copepodites & 0 & .05 & 0 & 0 & 0 & .08 & .60 & & & & 68 & .96 & .38 \\
\hline Other copepodites & 0 & & & & & 10 & & .06 & .39 & .36 & 0 & & \\
\hline Bivalve veligers & & & & & & & & 0 & & & .02 & & 0 \\
\hline Gastropod veligers & 0 & 0 & & 0 & 0 & 0 & & & 0 & 0 & 0 & 0 & 0 \\
\hline Miscellaneous & 17 & 0 & 0 & 0 & 0 & & 0 & 0 & 0 & 0 & 0 & 0 & \\
\hline Mean fish length (mm) & 12.0 & 11.9 & 12.3 & 11.8 & 12.3 & 12.3 & 13.3 & 15.7 & 17.2 & 17.3 & 18.0 & 17.7 & 18.5 \\
\hline
\end{tabular}


Table 3. Clupea harengus. Chi-square comparison of frequency distributions of available and ingested particles in selection experiments. First size and then type of particles is considered

\begin{tabular}{|c|c|c|c|c|c|c|}
\hline \multirow[b]{2}{*}{ Experiment } & \multicolumn{3}{|c|}{ Size } & \multicolumn{3}{|c|}{ Type } \\
\hline & $x^{2}$ & d. $f$ & p & $x^{2}$ & d. f. & $\mathrm{p}$ \\
\hline $1 \mathrm{~A}$ & 13.6 & 3 & $<0.005$ & 15.0 & 2 & $<0.005$ \\
\hline $1 \mathrm{~B}$ & 55.9 & 5 & $<0.005$ & 24.7 & 3 & $<0.005$ \\
\hline $2 \mathrm{~A}$ & 15.4 & 2 & $<0.005$ & 17.9 & 1 & $<0.005$ \\
\hline $2 B$ & 25.0 & 4 & $<0.005$ & 10.3 & 2 & $<0.010$ \\
\hline $2 \mathrm{C}$ & 8.9 & 2 & $<0.025$ & 10.2 & 2 & $<0.010$ \\
\hline $3 \mathrm{~A}$ & 34.2 & 5 & $<0.005$ & 11.0 & 3 & $<0.025$ \\
\hline $3 \mathrm{~B}$ & 20.0 & 3 & $<0.005$ & 45.7 & 3 & $<0.005$ \\
\hline 4 & 168 & 3 & $<0.005$ & 2.86 & 2 & n. s. \\
\hline $5 \mathrm{~A}$ & 560 & 4 & $<0.005$ & 306 & 3 & $<0.005$ \\
\hline $5 \mathrm{~B}$ & 60.1 & 4 & $<0.005$ & 24.1 & 4 & $<0.005$ \\
\hline $6 \mathrm{~A}$ & 193 & 5 & $<0.005$ & 18.4 & 2 & $<0.005$ \\
\hline $6 \mathrm{~B}$ & 2293 & 6 & $<0.005$ & 554 & 4 & $<0.005$ \\
\hline 7 & 1959 & 7 & $<0.005$ & 181 & 4 & $<0.005$ \\
\hline
\end{tabular}

Table 4. Clupea harengus. Alpha for various particle types in relation to fish length. Only results from experiments in which the 3 respective particle types were available were used to compute alpha. The mean and either $\pm 95 \% \mathrm{CL}(\overline{\mathrm{x}})$ or replicate values are shown

\begin{tabular}{|c|c|c|c|c|}
\hline \multirow[b]{2}{*}{$\begin{array}{l}\text { Fish length } \\
(\mathrm{mm})\end{array}$} & \multirow[b]{2}{*}{$\begin{array}{l}\text { No. of } \\
\text { expts. }\end{array}$} & \multicolumn{3}{|c|}{ Alpha } \\
\hline & & $\begin{array}{l}\text { Copepod } \\
\text { nauplii }\end{array}$ & $\begin{array}{l}\text { Copepo- } \\
\text { dites }\end{array}$ & $\begin{array}{l}\text { Veli- } \\
\text { gers }\end{array}$ \\
\hline $12.6 \pm 1.6$ & 6 & $76 \pm .22$ & $.21 \pm .20$ & 0 \\
\hline $17.7 \pm 1.0$ & 4 & $.19 \pm .35$ & $.81 \pm .34$ & $.01 \pm .02$ \\
\hline
\end{tabular}

(B) Only copepodites

\begin{tabular}{ccccc}
\multirow{2}{*}{$\begin{array}{c}\text { Fish length } \\
(\mathrm{mm})\end{array}$} & $\begin{array}{c}\text { No. of } \\
\text { expts. }\end{array}$ & $\begin{array}{c}\text { Pseudo- } \\
\text { calanus sp. }\end{array}$ & $\begin{array}{c}\text { Acartia } \\
\mathrm{sp} .\end{array}$ & $\begin{array}{c}\text { Oithona } \\
\mathrm{sp}\end{array}$ \\
\hline $12.4 \pm 1.0$ & 4 & $.72 \pm .43$ & $.04 \pm .04$ & $.24 \pm .41$ \\
$18.1(17.7,18.5)$ & 2 & $.30(.03, .57)$ & $.02(.01, .04)$ & $.67(.96, .38)$
\end{tabular}

the size distribution of available and ingested particles not significantly different (Table 3). In the second case, only particle types ingested at least once in an experiment were used to calculate alpha (Fig. 3, open circles). In both cases, particles narrower than the widest available and acceptable were preferred.

\section{Particle Rejection}

Feeding by herring larvae between 13 and $15 \mathrm{~mm}$ long was visually observed. Alpha and beta were calculated for the dominant particle types (Table 5). Mollusc veligers comprised only $11 \%$ of the available yet $25 \%$ of the rejected particles. Copepod nauplii and copepodites comprised $48 \%$ and $32 \%$ of the available particles, while only $8 \%$ and $11 \%$ of the rejected particles. Other particle types commonly perceived and investigated but always rejected were annelid larvae, Halosphaera viridis (Chlorophyta, Prasinophyceae), and detritus, including copepod exuvia and feces of herring larvae. Alpha and beta were also computed for four classes of particle widths (Table 6). Small and medium sized particles were both preferentially ingested and rejected, suggesting that particle size alone was not the cause of particle rejection.

Table 5. Clupea harengus. Alpha and beta for particle sizes frequently ingested or rejected by herring larvae in rejection experiments

\begin{tabular}{lll|}
\hline Particle type & $\alpha$ & $\beta$ \\
\hline Copepod nauplii & .54 & 10 \\
Pseudocalanus sp. copepodites & .27 & .08 \\
Oithona sp. copepodites & .08 & .01 \\
Other copepodites & .10 & .13 \\
Mollusc veligers & 0 & .67 \\
\hline
\end{tabular}

Table 6. Clupea harengus. Chi-square comparison of frequency distributions of available and ingested particles in rejection experiments. All types of particles in each experiment were considered

\begin{tabular}{|ccc|}
\hline Particle width $(\mu \mathrm{m})$ & $\alpha$ & $\beta$ \\
\hline$<80$ & 0.40 & 0.17 \\
$80-139$ & 0.36 & 0.37 \\
$140-199$ & 0.24 & 0.27 \\
$>200$ & 0 & 0.19 \\
$\chi_{3}^{2}$ & 11.0 & 22.1 \\
$p$ & $<0.025$ & $<0.005$ \\
\hline
\end{tabular}



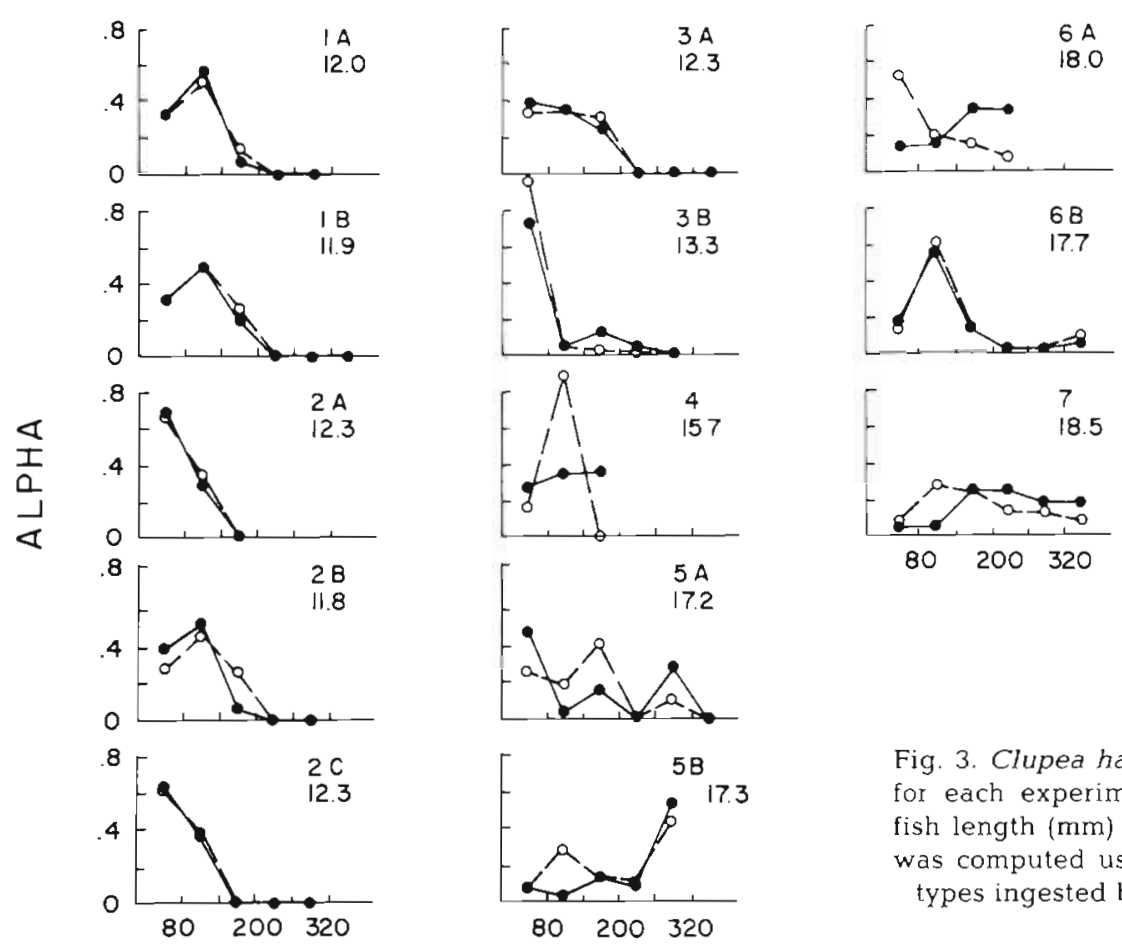

\section{PARTICLE WI \\ DISCUSSION AND CONCLUSION}

The initiation of feeding by herring with yolk has been observed for both wild (Lebour, 1924; Bhattacharyya, 1957) and reared (Rosenthal and Hempel, 1970) larvae. An asymptotic relation between the portion of fish with food at day's end and their age is expected for a population whose members commence feeding at different ages and where capture success increases with age. The asymptotic value $(83 \pm 13 \%)$ reported here exceeds most values observed for herring larvae collected at sea (e.g. 39\%, Lebour, 1924; $30 \%$, Marshall et al., 1937; $35 \%$, Bhattacharyya, 1957 ; $50 \%$ for North Sea, $84 \%$ for Baltic Sea, Schnack, 1972; $35 \%$, Last, $1980 ;<49 \%$, Cohen and Lough, 1981). Fish larvae caught at sea may void their gut upon capture, feed less often than reared larvae, or both.

The types of particles eaten by herring larvae in the present study became less diverse as fish aged. Food types other than copepods, including moliusc veligers, phytoplankton, and unidentifiable items, comprised $24 \%$ of the diet of young herring larvae but only $1 \%$ of the diet of older larvae. A similar trend in diet composition has been observed for wild herring (Lebour, 1924), with yolk sac larvae ingesting approximately equal amounts of phytoplankton, mollusc veligers, and copepods and post-yolk sac larvae eating primarily copepods. Less frequently, herring larvae have been collected at sea after yolk absorption with mollusc veligers being the dominant food type in their guts (Bowers and Williamson, 1951; Bhattacharyya, 1957; Schnack, 1972). Mollusc veligers are ingested by young herring larvae reared in the laboratory (Lasker et al., 1970, and references therein). Hence, the pattern of diet composition observed here is consistent with that observed in other studies of wild and reared herring larvae.

Larger fish ate larger prey but smaller than predicted by theory based on size alone. If food is selected in relation to its size rather than type, large particles would comprise a greater fraction of the diet than of the available particle assemblage and alpha would increase with particle size. Contrary to expectation, alpha was greatest for small particles (Fig. 3). When only acceptable types of particles (i.e. primarily copepad nauplii and copepodites) are used to calculate alpha, similar results obtain. The visibility and, hence, perception of a particle is related to its inherent contrast and movement (Kislalioglu and Gibson, 1976; Eggers, 1977), in addition to its size. Both copepod nauplii and copepodites are of similar contrast. Prey movement increases visibility and should favor the perception of larger, faster copepodites. Beyer (1980) predicted that the optimal width of herring larvae prey is positively related to but less than the mouth gape, based on the probability of successful strikes on different sized prey. Beyer's optimal prey widths are significantly greater than the mean or preferred prey 
widths observed in the present study. Cohen and Lough (1981) found the mean width of prey in wild herring larvae was also narrower than Beyer's prediction of optimal width, although the size of available particles is unknown. Hence, the observed selection for small prey does not appear to result from variations in prey visibility due to size, contrast, or movement. Copepodites are known to avoid predators more successfully than are copepod nauplii (Landry, 1978). Similar selection for prey smaller than predicted on the basis of prey visibility and optimal foraging was shown for northern anchovy (Engraulis mordax) larvae (Arthur, 1976), 15-spined stickleback (Kislalioglu and Gibson, 1976), and juvenile chum salmon (Feller and Kaczynski, 1975).

Certain types of particles were preferred by older larvae. Although the particle assemblage available to 4 to $24 \mathrm{~d}$-old fish is not known, their diet suggests they were less selective than older larvae, who fed exclusively on copepod nauplii and copepodites (Table 1). Mollusc veligers, phytoplankters, especially Halosphaera viridis, and detrital particles were available to older larvae yet never ingested; particles of these types were often perceived, inspected, and rejected. Mollusc veligers, in particular, were perceived, probably due to the opacity of their shell and resultant high visibility, and rejected out of proportion to their availability (Tables $4 \mathrm{a}$ and 5). The size distributions of rejected and ingested particles were similar (Table 6). These results suggest that the type rather than the size of particles was the primary criterion for acceptance or rejection.

The preference for Pseudocalanus sp. and Oithona sp. and avoidance of Acartia sp. copepodites is further evidence for selection by type rather than size. The gut contents of larvae collected at sea show similar patterns (Hardy, 1924; Lebour, 1924; Marshall et al., 1937; Bowers and Williamson, 1951; and Last, 1980). Each species of copepod has a characteristic pattern of movement by which, in addition to size, shape and color, it may be recognized (Shuvayev, 1979). Acartia sp. has the greatest burst speed and perhaps ability to escape. Hence, the observed preferences may reflect either differential visibility, escape capability, or both.

The lack of feeding on certain particle types probably reflects their nutritional value (assimilable energy or protein) to herring larvae and results from experience. Detrital particles, including copepod exuvia and the feces of herring larvae, are of comparatively low nutritional value. When ingested, Halosphaera viridis and mollusc veligers showed little evidence of digestion, even amongst digested copepods, in the posterior of the hindgut. Mollusc veligers enhanced the growth of food-limited northern anchovy larvae only slightly (Lasker et al., 1970) and appeared undigested in the guts of northern anchovy (Arthur, 1976) and herring larvae (Bhattacharyya, 1957; Schnack, 1972) collected at sea. Mollusc larvae are known, at times, to pass live through their predators' guts (Mileikovsky, 1974). Hence, experienced herring larvae appear to reject particles of low and select those of high nutritional value, especially copepods. Recognition of different prey types may depend on prey shape, contrast, and movement, in addition to size. Scura and Jerde (1977) observed analagous preferences for certain types of phytoplankton by northern anchovy Engraulis mordax and suggested nutritional value as a criterion for acceptance or rejection.

Herring larvae appeared unable to digest all copepod lipids. The remains of late stage copepodites of Pseudocalanus sp. in the posterior portion of the hindgut of larval herring consisted of carapaces and oil droplets (Fig. 1 A). Juvenile and adult herring assimilate copepod lipids, perhaps due to their retention and digestion in the pyloric caecae (Sargent et al., 1979). Larval herring have a straight gut and lack caecae and, hence, may be unable to digest copepod lipids. The inefficient assimilation of lipids may reduce the preference by larval herring for large, late-stage copepodites containing oil. Juvenile and adult herring would benefit by selecting such prey, however.

The presence of mollusc veligers and other food of low nutritive value in the guts of larval herring may reflect the inexperience of young larvae and the lack of more nutritious food for old larvae in nature. Selection for food of greatest nutritional value (e.g. copepods) increased with age in the present study and has, in general, been observed for herring larvae in culture (Rosenthal and Hempel, 1970) and collected at sea (Lebour, 1924; Bowers and Williamson, 1951; Schnack, 1972). Veligers, however, occasionally dominate the diets of wild larvae (Lebour, 1924; Bowers and Williamson, 1951; Bhattacharyya, 1957; Schnack, 1972). Similarly, the diet of northern anchovy larvae at times is dominated by pteropod mollucs (Arthur, 1976) and the dinoflagellate Gonyaulax polyedra (Scura and Jerde, 1977), both of doubtful nutritive value. In the absence of more nutritious foods, herring and other fish larvae may ingest food of low value. The frequency and significance of this occurrence in nature is unknown.

Predators on the plankton are often typed as invertebrate or vertebrate (Brooks and Dodson, 1965; Steele and Frost, 1977). Invertebrate predators select small prey while vertebrate predators select large prey from their respective assemblages of available prey. My results suggest that herring behave, as larvae, like invertebrate predators. The results of Hardy (1924) indicate that juvenile and adult herring behave like vertebrate predators, preferring large copepods. 
Hence, the predatory behavior of herring may develop from the invertebrate type for the planktonic larvae to the vertebrate type for the nektonic juveniles and adults.

In conclusion, herring larvae select food on the basis of type as well as size. Feeding behavior consists of particle perception, the decision to attack or reject the perceived particle, and the attack. Differential visibility appears to affect perception of particles of the same size but different types, such as mollusc veligers and copepods with high and low contrast, respectively. The decision to attack or reject a particle is related to the type of the particle as well as to its size and probably depends on the particle's nutritive value to the larvae. The success of an attack will depend on the escape ability and, hence, type of the potential prey. Future investigations, including realistic models, of feeding by larval fish should consider both the type and size of particles available in the sea.

Acknowledgements. This research was made possible by a NATO Postdoctoral Fellowship in Science awarded to D Checkley. The support of the Marine Laboratory of the Department of Agriculture and Fisheries for Scotland, especially Dr. J. Gamble, was invaluable. The crew of the 'Green Pastures' and the salmon fishermen of Aberdeen also provided valuable assistance. Drs. $K$. Sherman, $H$. von Westernhagen, J. Yen, and an anonymous reviewer made constructive comments.

\section{LITERATURE CITED}

Arthur, D. K. (1976). Food and feeding of larvae of three fishes occurring in the California Current, Sardinops sagax, Engraulis mordax, and Trachurus symmetricus. Fish. Bull. U.S. 74: $517-530$

Beyer, Jan E. (1980). Feeding success of clupeoid fish larvae and stochastic thinking. Dana 1: 65-91

Bhattacharyya, R. N. (1957). The food and feeding habits of larval and postlarval herring in the northern North Sea. Mar. Res. 3: 1-14

Blaxter, J. H. S. (1965). The feeding of herring larvae and their ecology in relation to feeding. Rep. Calif. Coop. Oceanic Fish. Invest. 10: 79-88

Blaxter, J. H. S. (1968). Rearing herring larvae to metamorphosis and beyond. J. mar biol. Ass. U. K. 48: 17-28

Brooks, J. L., Dodson, S. I. (1965). Predation, body size, and composition of plankton. Science, N. Y. 150: 28-35

Bowers, A. B., Williamson, D. J. (1951). Food of larval and early postlarval stages of autumn-spawned herring in Manx-waters. Rep. mar. biol. Sta. Pt. Erin 63: 17-26

Chesson, J. (1978). Measuring preference in selective predation. Ecology 59: 211-215

Cohen, R. E. Lough, R. G. (1981). Larval herring food habits over three spawning seasons (1974-76) in the Georges Bank-Nantucket Shoals area. Coun. Meet. int. Coun Explor. Sea (C. M. I.C.E.S.) H: 59

Confer, J. L., Blades, P. I. (1975). Omnivorous zooplankton and planktivorous fish. Limnol. Oceanogr. 20:571-579

Eggers, D. M. (1977). The nature of prey selection by planktivorous fish. Ecology 58: 46-59
Feller, R. J., Kaczynski, V W. (1975). Size selective predation by juvenile chum salmon (Oncorhynchus) on epibenthic prey in Puget Sound. J. Fish. Res. Bd Can. 32: 1417-1429

Hardy, A. C. (1924). The herring in relation to its animate environment. Part I. The food and feeding habits of the herring with special reference to the east coast of England. Fishery Invest. Lond. (Ser. 2) 7 (3): 1-53

Kislalioglu, M., Gibson, R. N. (1976). Some factors governing prey selection by the 15-spined stickleback, Spinachia spinachia L. J. exp. mar. Biol. Ecol. 25: 159-169

Landry, M. R. (1978). Predatory feeding behavior of a marine copepod, Labidocera trispinosa. Limnol. Oceanogr. 23: 1103-1113

Lasker, R., Feder, H. M., Theilacker, G. H., May, R. C. (1970). Feeding, growth, and survival of Engraulis mordax larvae reared in the laboratory. Mar. Biol. 5: 345-353

Last, J. M. (1980). The food of twenty species of fish larvae in the west-central North Sea. Fish. Res. Tech. Report No. 60

Lebour, M. V. (1924). The food of young herring. J. mar. Biol. Ass. U. K. 13: 325-330

Lebour, M. V. (1933). The importance of larval mollusca in the plankton. J. Cons. perm. int. Explor. Mer 8: 335-343

Marshall, S. H., Nicholls, A. G., Orr, A. P. (1937). On the growth and feeding of the larval and postlarval stages of the Clyde herring. J. mar. biol. Ass. U. K. 22: 245-267

Mileikovsky, S. A. (1974). On predation of pelagic larvae and early juveniles of marine bottom invertebrates by adult benthic invertebrates and their passing alive through their predators. Mar. Biol. 26: 303-311

Murdoch, W. W. (1969). Switching in general predators: experiments on predator specificity and stability of prey populations. Ecol. Monogr. 39: 335-354

Pyke, G. H., Pulliam, H. R., Charnov, E. L. (1977), Optimal foraging: a selective review of theory and tests. $Q$. Rev. Biol. 52: 137-154

Rosenthal, H. (1967). Parasites in larvae of the herring (Clupea harengus L.) fed with wild plankton. Mar. Biol. 1: $10-15$

Rosenthal, H., Hempel, G. (1970). Experimental studies in feeding and food requirements of herring Iarvae (Clupea harengus L.). In: Steele, J. H. (ed.) Marine food chains. Oliver and Boyd, Edinburgh, pp. 344-363

Sargent, J. R., McIntosh, R., Bauermeister, A., Blaxter, J. H. S (1979). Assimilation of the wax esters of marine zooplankton by herring (Clupea harengus) and rainbow trout (Salmo gairdnerii). Mar. Biol. 51: 203-207

Schnack, D. (1972). Studies on the food ecology of herring larvae, [transl. from Russian by E. Parsons, No. 1942 of DAFS, Aberdeen]. Ber. dt. wiss. Kommn Meeresforsch. 22: $273-343$

Scura, E. D., Jerde, C. W (1977). Various species of phytoplankton as food for the larval northern anchovy, Engraulis mordax, and relative nutritional value of the dinoflagellates Gymnodinium splendens and Gonyaulax polyedra. Fish. Bull. U. S. 75: 577-583

Sherman, K., Honey, K. A. (1971). Seasonal variations in the food of larval herring in coastal waters of central Maine. Rapp. P.-v. Réun. Con. perm. int. Explor. Mer 160: $121-124$

Shirota, A. (1970). Studies on the mouth size of fish larvae, [transl. by Fish. Res. Bd Can., Transl. Ser. 1978.] Bull. Japan Soc. Sci. Fish. 36: 353-368

Shuvayev, Yn. D. (1979). Movements of some planktonic copepods. Hydrobiol. J. 14: 32-36

Steele, J. H., Frost, B. W. (1977). The structure of plankton communities. Phil. Trans. R. Soc. (B) 280: 485-535 
Ware, D. M. (1973). Risk of epibenthic prey to predation by rainbow trout (Salmo gairdnerii). J. Fish. Res. Bd Can. 30: $787-797$
Werner, E. E., Hall, D. J. (1974). Optimal foraging and the size selection of prey by the bluegill sunfish (Lepomis macrochirus). Ecology 55: 1042-1052

This paper was submitted to the editor; it was accepted for printing on May 15, 1982 